\title{
Management Plan for the Development of the License Application for a High-Level Waste Repository at Yucca Mountain
}

YMP/97-02

Revision 0 
Management Plan for the Development of the License Application

for a High-Level Waste Repository at Yucca Mountain

\section{CHANGE HISTORY}

\section{REV.NO. ICNNO. EFFECTIVEDATE DESCRIPTION OF CHANGE}

Initial issue 
Stephan J. Brocoum

Date

Assistant Manager for Licensing

Yucca Mountain Site Chạacterịation Office<smiles>[Mg]</smiles>

Wesley E. Barnes, Project Manager

Date

Yucca Mountain Site Characterization Office 


\section{CONTENTS}

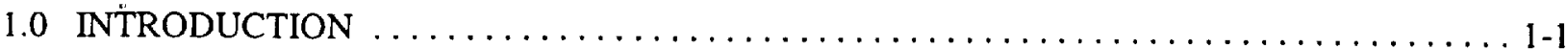

1.1 PURPOSE AND SCOPE OF THE LICENSE APPLICATION MANAGEMENT

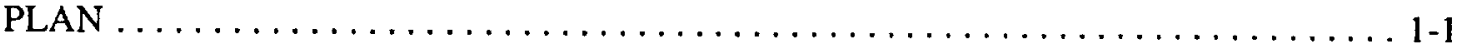

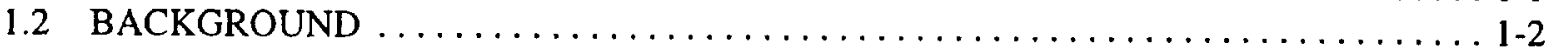

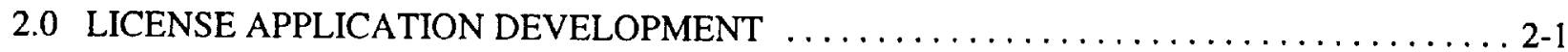

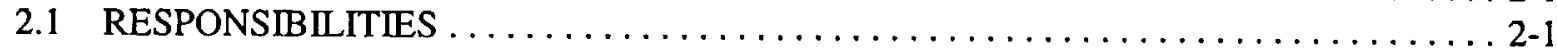

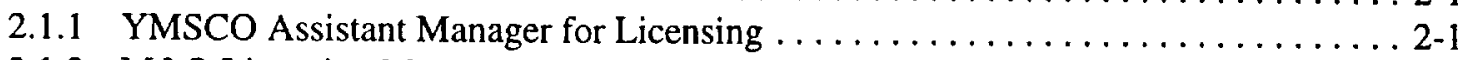

2.1.2 M\&O Licensing Manager ................................ $2-2$

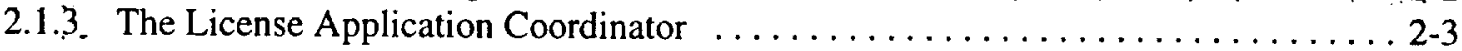

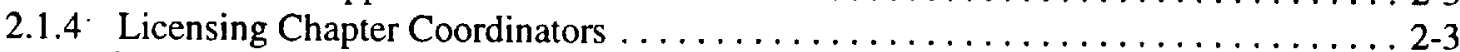

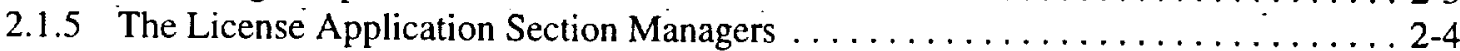

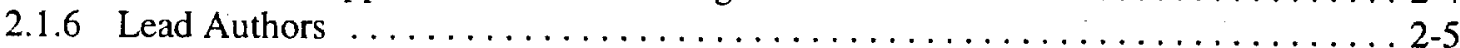

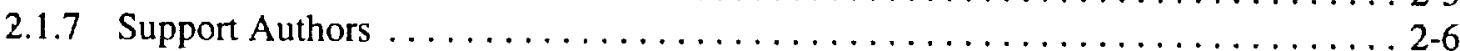

2.1.8 M\&O Training and Development Manager $\ldots \ldots \ldots \ldots \ldots \ldots \ldots \ldots \ldots \ldots \ldots \ldots$

2.1 .9 The License Application Reviewers . . . . . . . . . . . . . . . . . . . . . 2-7

2.1.10 License Application Consulting Board . . . . . . . . . . . . . . . . . . . 2-7

2.2 LICENSE APPLICATION DOCUMENT TABLE OF CONTENTS $\ldots \ldots \ldots \ldots \ldots \ldots .28$

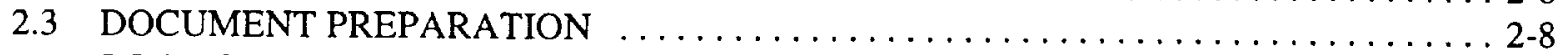

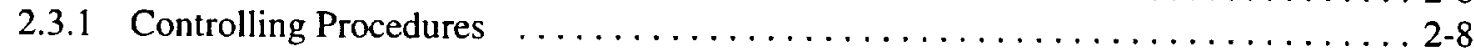

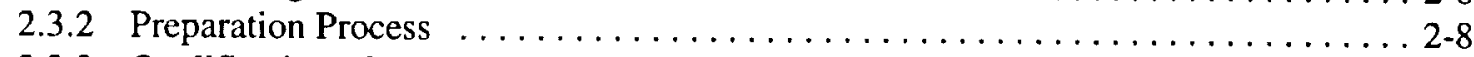

2.3.3 Qualification of the License Application Development Team Members ...... 2-11

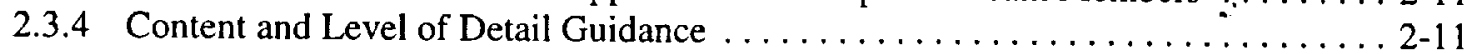

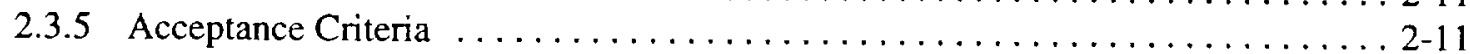

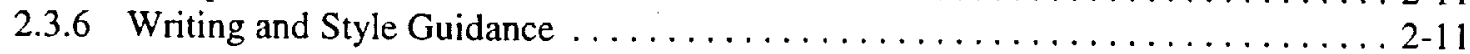

2.3.7 Incorporation of Documents, Position Papers, Policies, and Other Information . . . 2-12

2.3.7.1 License Application Annotated Outline ................ 2-12

2.3.7.2 Operating Experience Information $\ldots \ldots \ldots \ldots \ldots \ldots \ldots \ldots \ldots, 2-12$

2.3.7.3 Topical Reports ............................. 2-12

2.3.7.4 Other Documents ............................. 2-13

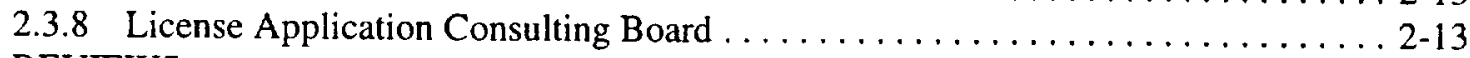

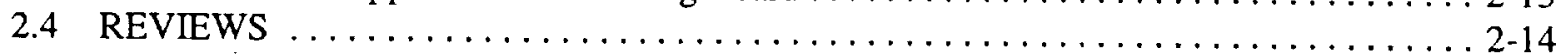

2.4.1 Reviews During License Application Development ................ 2-14

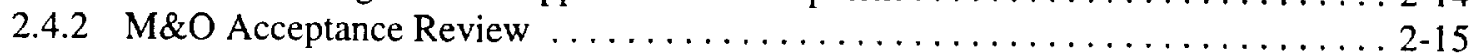

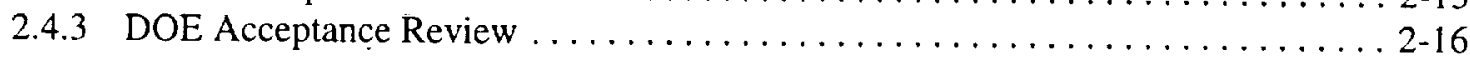

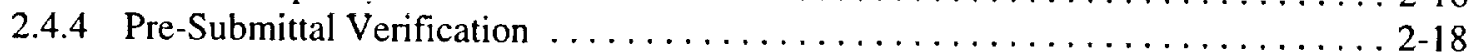

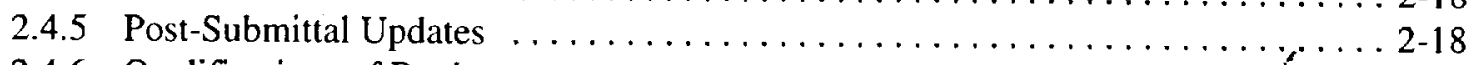

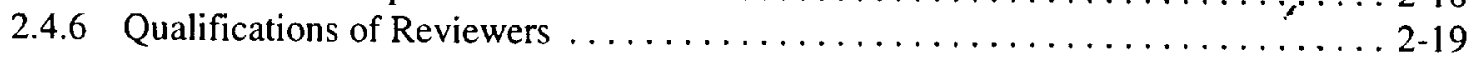

3.0 PROJECT MANAGEMENT AND CONTROL $\ldots \ldots \ldots \ldots \ldots \ldots \ldots \ldots \ldots \ldots \ldots \ldots \ldots .1$

3.1 ESTABLISHMENT AND MAINTENANCE OF THE PROJECT DEVELOPMENT

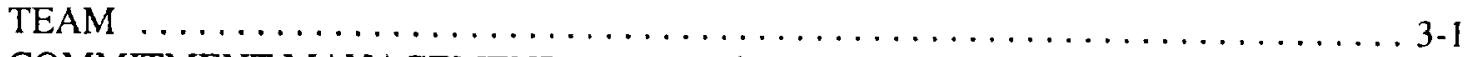

3.2 COMMITMENT MANAGEMENT AND TRACKING $\ldots \ldots \ldots \ldots \ldots \ldots \ldots \ldots \ldots \ldots \ldots \ldots \ldots \ldots$

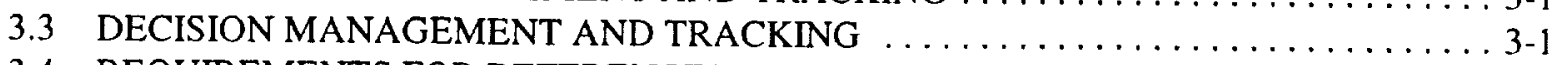

3.4 REQUIREMENTS FOR REFERENCES, DATA, AND ASSUMPTIONS $\ldots \ldots \ldots \ldots \ldots \ldots .2$ 
3.5 IDENTIFICATION AND TRACEABILITY OF REFERENCES, DATA, AND

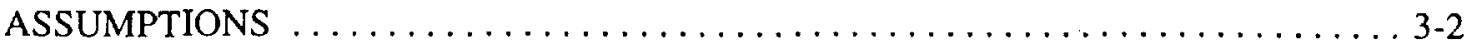

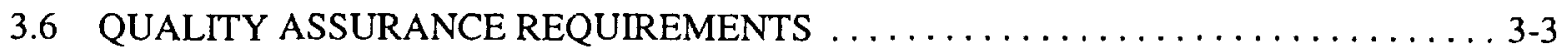

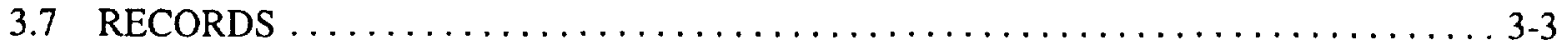

4.0 SCHEDULE AND MILESTONES FOR LICENSE APPLICATION DEVELOPMENT

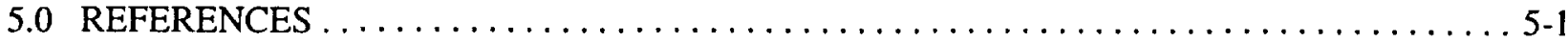

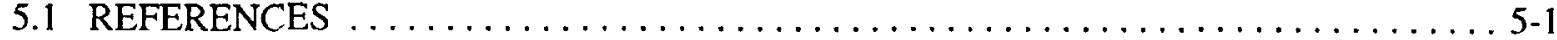

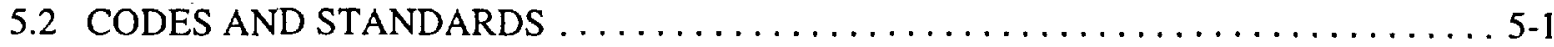

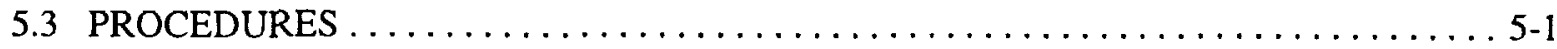

APPENDIX A ACRONYMS AND ABBREVIATIONS $\ldots \ldots \ldots \ldots \ldots \ldots \ldots \ldots \ldots \ldots$ A-1 


\subsection{INTRODUCTION}

The U.S. Department of Energy (DOE) plans to file a license application with the U.S. Nuclear Regulatory Commission (NRC) pursuant to 10 CFR 60, Disposal of High-Level Radioactive Wastes in Geologic Repositories (10 CFR 60). The NRC, in accordance with 10 CFR 60, will evaluate DOE's application to receive and possess source, special nuclear, and byproduct material at a geologic repository operations area (hereafter referred to as the "License Application"), and the accompanying Environmental Impact Statement, before issuing an authorization to construct the proposed geologic repository. The NRC will issue a license to DOE under Part 60 only after construction of the geologic repository operations area is substantially complete and the initial License Application has been updated in accordance with 10 CFR 60.24.

This document provides guidance for managing the process for filing a License Application under 10 CFR 60 that will enable the NRC to issue DOE a construction authorization pursuant to 10 CFR 60.31 .

\subsection{PURPOSE AND SCOPE OF THE LICENSE APPLICATION MANAGEMENT PLAN}

The purpose of this document, hereafter called "the Management Plan," is to provide direction for development of a License Application, in compliance with 10 CFR 60.21, sufficient to receive authorization from $N R C$ to construct a high-level radioactive waste repository at Yucca Mountain. The License Application consists of general information and a Safety Analysis Report. It is to be accompanied by an Environmental Impact Statement. (Because the Environmental Impact Statement is a companion to, but not part of the License Application, it is not covered by this Management Plan.) This Management Plan primarily describes the process to be used for developing the License Application, outlines the information to be provided in the License Application, and establishes a format for presenting the information. Revisions to this Management Plan will provide guidance for developing and submitting updates to the License Application that will be required before NRC issues DOE a license under 10 CFR 60 .

Specific objectives of the Management Plan include:

- Explain the development process for the License Application, including the DOE and Management and Operating Contractor $(\mathrm{M} \& \mathrm{O})$ review and comment resolution.

- Explain the management framework and oversight process for License Application development.

- Describe responsibilities of key personnel in the License Application development effort.

- Provide guidance for the mechanics of development of the License Application.

- Provide guidance for the identification and traceability of data and reference documents that support the License Application.

- Provide guidance for selection and qualification of License Application development team members. 
- Provide for integration of information from previous activities on the Yucca Mountain Site Characterization Project (YMP) into the License Application.

- Explain how operating experience information from similar nuclear and/or industrial facilities is to be incorporated into the License Application development process.

- Specify the License Application-associated records to be captured and retained and the process for capture and retention.

- Explain quality assurance requirements applicable to the License Application and its supporting references and data.

The Management Plan and the License Application will be DOE-controlled documents. Copies of the Management Plan will be issued to Yucca Mountain Site Characterization Office (YMSCO) offices (as assigned by the YMSCO Assistant Manager for Licensing); DOE Headquarters; M\&O management (to the Office Manager level); each License Application Section Manager, lead author, support author, reviewer, technical leads; and other individuals requesting a copy. Copies of the License Application, including the Working Draft, will be issued to YMSCO offices (as assigned by the YMSCO Assistant Manager for Licensing), DOE Headquarters, M\&O management (to the Office Manager level), and to other users as designated by the YMSCO Assistant Manager for Licensing and by the M\&O Licensing Manager.

Distribution of paper copies of the License Application will be limited because of the great size of the completed License Application. It is expected that the License Application submitted to the NRC will be widely available in electronic form to persons inside and outside the Project.

Future revisions to the Management Plan will be made when considered necessary. by the YMSCO Assistant Manager for Licensing.

The scope of the Management Plan includes guidance for all the above activities and general guidance for License Application development. Specific requirements or guidance provided in this document may be waived at the discretion of the YMSCO Assistant Manager for Licensing or as otherwise noted in this document. Such waivers shall be documented as decisions pertinent to License Application development in accordance with Section 3.3.

The Management Plan was developed under the requirements of DOE/RW-0333P, Quality Assurance Requirements and Description (DOE 1997). Implementing procedures were YAP5.1Q, Submittal of Documents for Development, Change, Review, and Deliverable Acceptance, and YAP-5.8Q, Technical Document Preparation. This document has been determined to not be quality affecting, and is therefore not subject to quality assurance controls. Review of the document was performed in accordance with QAP 6.2, Document Review.

\subsection{BACKGROUND}

The Management Plan is one of three YMP products being developed in direct support of licensing the proposed high-level waste repository at Yucca Mountain in Nevada. The other two products are the License Application Plan (YMP in prep), which provides specified information on Project activities and costs required to obtain necessary information and support successful completion of the License Application; and the Technical Guidance Document for License Application Preparation (YMP in prep.) (Technical Guidance Document) which provides content and acceptance criteria guidance for development of the License Application. 
DOE plans to submit the License Application to the NRC in 2002. Under the Nuclear Waste Policy Act of 1982, as amended (the NWPA), this submittal is contingent upon the Secretary of Energy sending a recommendation to the President that he approve the site for the development of a repository, the President recommending the site to Congress, and the designation of the site then becoming effective under Section 115 of the NWPA. The DOE has 90 days from the date that the site designation becomes effective to submit the License Application to the NRC. This Management Plan provides the framework to ensure that the License Application is developed on schedule and with adequate content to be submitted to the NRC in accordance with the NWPA. 


\subsection{LICENSE APPLICATION DEVELOPMENT}

This chapter describes the mechanics of how the License Application will be controlled, developed, reviewed, and approved.

\section{$2.1 \quad$ RESPONSIBILITIES}

This section describes the responsibilities of specific individuals during development of the License Application.

\subsubsection{YMSCO Assistant Manager for Licensing}

The YMSCO Assistant Manager for Licensing is responsible to the Manager, YMSCO for successful and on-time development of the License Application. Because the License Application will be developed by the M\&O, the YMSCO Assistant Manager for Licensing is responsible for oversight of the $\mathrm{M} \& \mathrm{O}$ development work for the License Application. The Assistant Manager for Licensing or designee is also responsible for coordinating review and approval of the License Application and the Working Draft License Application (discussed in Section 2.4.1) within the DOE.

The YMSCO Assistant Manager for Licensing is specifically responsible for the following activities, which may be delegated to the $\mathrm{M} \& \mathrm{O}$ while retaining responsibility:

- Developing and approving technical requirements and acceptance criteria to support licensing.

- Developing, approving, and implementing schedules to support licensing.

- Developing and approving budgets to support licensing.

- Reviewing and approving the License Application.

- Submitting the License Application to the Program Director for subsequent processing and transmittal to the NRC on schedule and in appropriate form and content to support docketing and subsequent issuance of a construction permit.

- Ensuring personnel assigned to develop and review the License Application are properly trained and qualified.

- Ensuring the quality of data and information to be provided and referenced in the License Application, as required by DOE/RW-0333P, Quality Assurance Requirements and Description (DOE 1997).

- Informing cognizant DOE Headquarters management of issues that could impact the success or timeliness of the License Application development process, and addressing such issues to minimize potential impacts. 


\subsubsection{M\&O Licensing Manager}

The $\mathrm{M} \& \mathrm{O}$ Licensing Manager is the $\mathrm{M} \& \mathrm{O}$ manager responsible for activities associated with the development of the License Application and for implementation of the Management Plan. The Licensing Manager is responsible for the development process and is responsible for providing periodic status updates to YMSCO and M\&O management.

The responsibilities of the $M \& O$ Licensing Manager include:

- Supervising development of the License Application.

- Working with $\mathrm{M} \& O$ management to achieve assignment of appropriate personnel as License Application section managers and lead ạthors for each License Application șęction.

- Ensuring appropriate controls are implemented such that data and information presented in the License Application are appropriately consistent throughout the document.

- Developing a schedule for completion of the License Application and ensuring compliance with that schedule.

- Tracking the License Application development process and providing the License Application status to YMSCO.

- Coordinating the License Application development process with YMSCO staff designated to coordinate the License Application development, and serving as the primary interface between the $\mathrm{M} \& \mathrm{O}$ and YMSCO for the License Application development.

- $\quad$ Providing Licensing Department staff support (or support from other M\&O personnel as necessary) for facilitating training, as necessary, on the License Application development, and iterative reviews and regulatory consultation to the License Application lead and support authors.

- Reviewing regulatory documents, technical materials, reports, requirements, studies, and the License Application chapters in progress; and providing comment and feedback to authors.

- Coordinating final consolidation and editing of the License Application for YMSCO review and approval.

- $\quad$ Ensuring appropriate records are processed as required by AP-17.1Q, Record Soyirce Responsibilities for Inclusionary Records.

- Convening and coordinating the activities of the License Application Consulting Board as discussed in Section 2.3.8 and ensuring that the recommendations of the Board are appropriately addressed. 
- $\quad$ Providing a list of designated $M \& O$ License Application development team members to $\mathrm{M} \& \mathrm{O}$ Training and Development, and working with $\mathrm{M} \& \mathrm{O}$ Training and Development to ensure that all designated team members are qualified and that qualification is properly documented.

\subsubsection{The License Application Coordinator}

The License Application Coordinator is the person in the M\&O Licensing Department responsible to the $\mathrm{M} \& \mathrm{O}$ Licensing Manager for coordinating development of the License Application.

The responsibilities of the License Application Coordinator include:

Ensuring that the License Application is developed on schedule in a form acceptable to the NRC for docketing.

- Ensuring that the License Application is developed in compliance with this Management

- Plan and with the Technical Guidance Document for License Application Preparation (YMP in prep.) (Technical Guidance Document).

- Informing cognizant M\&O and YMSCO management (including the License Application Section Managers) of issues that could impact the success or timeliness of the License Application development process, and addressing such issues to minimize potential impacts.

- Coordinating the efforts of licensing chapter coordinators and lead authors to. support successful development of the License Application.

- Ensuring required records are created and submitted in accordance with AP-17.1Q.

\subsubsection{Licensing Chapter Coordinators}

The licensing chapter coordinators are individuals assigned by the $\mathrm{M} \& \mathrm{O}$ Licensing Manager to coordinate development of assigned License Application chapters.

The responsibilities of the licensing chapter coordinators include:

- Being responsible to the License Application Coordinator and the M\&O Licensing Manager for monitoring the status of assigned chapter development.

- Working with associated lead and supporting authors to ensure that assigned chapters are developed with adequate content to support the License Application submittal and on time.

- Providing appropriate licensing perspective to the associated lead authors and support authors.

- Editing the assigned draft chapters and sections for content, compliance with regulatory requirements, format, and consistency with other chapters and sections. 
- Monitoring development status of assigned chapters and taking appropriate action to ensure that issues and problems with development of assigned chapters are expeditiously addressed so as not to adversely impact product quality or schedule.

- Ensuring that the License Application Coordinator and M\&O Licensing Manager are informed of chapter development status and of any issues that could impact successful, ontime development of assigned chapters and sections, and expeditious resolution of such issues.

\subsubsection{The License Application Section Managers}

The License Application section managers are the $\mathrm{M} \& \mathrm{O}$ personnel selected by $\mathrm{M} \& \mathrm{O}$ senior management to have the overall responsibility for the technical content and timely development of the License Application chapters and sections.

The responsibilities of the License Application section managers include:

- Functioning as the ultimate technical authorities for the development of the License Application chapters assigned to their respective organizations.

- Assigning lead authors and support authors, if necessary, for each License Application section, as appropriate.

- Ensuring, in cooperation with the M\&O Licensing Manager, that each lead and support author within respective organizations is qualified and trained to the applicable procedures, and submitting training and qualification documentation to the M\&O Training and Development Manager as specified in Section 2.3.3.

- Coordinating development of the License Application text, reviews, and comment resolution for assigned sections of the License Application. Reviews are performed by the $\mathrm{M} \& \mathrm{O}, \mathrm{YMSCO}$, and the DOE Headquarters organizations.

- Ensuring that all data and records utilized in the License Application are available and traceable as discussed in Section 3.5.

- Ensuring that source materials are correctly cited as references.

- Providing draft texts of the License Application sections as they are developed to the M\&O Licensing Manager for review and comment.

- Submitting completed sections of the License Application for review in accordance with the License Application development schedule and in accordance with Section 2.4.

- Providing the License Application section and chapter development status information as requested by the $\mathrm{M} \& O$ Licensing Manager.

- Informing the M\&O Licensing Manager of problems impacting the deliverable due dates.

- Ensuring that all alternative interpretations, supported by regional and site data, and analyses and conclusions relevant to the License Application are clearly discussed. 
Ensuring that any assumptions, the data, interpretations, alternative hypotheses, and a preferred hypothesis are clearly differentiated so that an independent reviewer can review the information and reach an independent conclusion. In addition, ensuring that 1 ) the rationale for disagreeing with all or parts of the data, analyses, or conclusions is provided, 2) the extent to which these altemative interpretations and this literature impact the YMP data and conclusions is discussed, and 3) the impact, if any, these alternative interpretations would have on repository performance is discussed.

\subsubsection{Lead Authors}

Lead authors are knowledgeable qualified individuals from the M\&O staff assigned by the License Application Section Manager to develop specific chapters or sections. These individuals have the primary responsibility for the quality of the technical content of assignments.

..

The responsibilities of the lead authors include:

- Developing assigned sections and chapters of the License Application in accordance with this Management Plan and with the Technical Guidance Document.

- Working with the licensing chapter coordinator(s) for chapters assigned to the lead author in whole or in part to ensure draft License Application text material incorporates appropriate regulatory perspective.

- Working with support authors, where assigned, to develop assigned sections of the License Application per the guidance presented in this Management Plan.

- Ensuring that all alternative interpretations, supported by regional and site data, and analyses and conclusions relevant to the License Application are clearly discussed. Ensuring any assumptions, the data, interpretations, alternative hypotheses, and a preferred hypothesis are clearly differentiated so that an independent reviewer can review the information and reach an independent conclusion. In addition, ensuring that 1) the rationale for disagreeing with all or parts of the data, analyses, or conclusions is provided, 2) the extent to which these alternative interpretations and this literature impact the YMP data and conclusions is discussed, and 3 ) the impact, if any, these alternative interpretations would have on repository performance is discussed. While section managers, lead authors, and support authors share this responsibility, it is expected that lead and support authors will actually incorporate the discussion in the License Application text.

- Ensuring that references or data to be provided in assigned chapters and sections meet applicable requirements discussed in Section 3.5.

- Ensuring that data and information presented in assigned chapters or sections are appropriately consistent with other places in the License Application in which such data and information are presented or used.

- Ensuring that, when expert judgement is used formally in assigned sections/chapters of the License Application, it is documented in accordance with YMP procedures and sufficient documentation is provided in the License Application. 
- Accessing data from the Geographic nodal Information Study and Evaluation System (GENISES) or Reference Information Base databases to support the License Application development.

- Submitting data to the GENISES or Reference Information Base databases as required by Project procedures. The lead author shall also ensure that the data and its supporting documentation have been submitted to the Office of Civilian Radioactive Waste Management (OCRWM) Records Processing Center for indexing and maintenance.

- Identifying and reviewing YMP and external documents for use and incorporation in preparing assigned sections of the License Application.

- Informing the pertinent License Application section manager and licensing chapter coordinator of problems and issues that could impact successful, on-time development of assigned chapters and sections, and expeditious resolution of such issues.

- In the case of the Quality Assurance chapter of the License Application, working closely - with the DOE Office of Quality Assurance during development of the chapter to ensure its acceptability to that organization.

\subsubsection{Support Authors}

Support authors are M\&O personnel assigned by the License Application Section Manager to assist the lead authors in developing parts of specific sections of the License Application.

The responsibilities of the support authors include:

- Being responsible to the pertinent lead author for development of assigned sections or subsections in accordance with the License Application development schedule, this Management Plan, and the Technical Guidance Document.

- Ensuring that all alternative interpretations, supported by regional and site data, and , analyses and conclusions relevant to the License Application are clearly discussed. Ensuring any assumptions, the data, interpretations, alternative hypotheses, and a preferred hypothesis are clearly differentiated so that an independent reviewer can review the information and reach an independent conclusion. In addition, ensuring that 1) the rationale for disagreeing with all or parts of the data, analyses, or conclusions is provided, 2) the extent to which these alternative interpretations and this literature impact the YMP data and conclusions is discussed, and 3) the impact, if any, these alternative interpretations would have on repository performance is discussed. While section managers, lead authors, and support authors share this responsibility, it is expected that lead and support authors will actually incorporate the discussion in the License Application text.

- Ensuring that references or data to be provided in assigned License Application chapters/sections meet applicable requirements in Section 3.5.

- Ensuring that data and information presented in assigned chapters or sections are appropriately consistent with other places in the License Application in which such data and information are presented or used. 
- Ensuring that, when expert judgement is used formally in the License Application, it is documented in accordance with YMP procedures and sufficient documentation provided in the License Application.

- Accessing data from the GENISES or Reference Information Base databases to support the License Application development.

- Submitting data to the GENISES or Reference Information Base databases as required by Project procedures. The supporting author shall also ensure that the data and its supporting documentation have been submitted to the OCRWM Records Processing Center for indexing and maintenance.

- Identifying and reviewing YMP documents for use and/or incorporation in preparing șections of the License Application.

- Informing the pertinent lead author of problems and issues that could impact successful, ontime development of assigned chapters and sections, and expeditious resolution of such - issues.

\subsubsection{M\&O Training and Development Manager}

The M\&O Training and Development Manager is responsible for facilitating qualification and training of $\mathrm{M} \& \mathrm{O}$ personnel involved in development of the License Application in accordance with this Management Plan and procedure QAP-2-1, Indoctrination and Training.

The M\&O Training and Development Manager is specifically responsible for:

- Ensuring that qualification of $\mathrm{M} \& O$ License Application development team members designated by the $\mathrm{M} \& \mathrm{O}$ Licensing Manager is documented in accordance with this Management Plan. This task includes providing M\&O Licensing and the section managers a list of qualified License Application lead and support authors before document production begins and informing M\&O Licensing and the section managers in writing of any , subsequent changes to the list.

- Working with M\&O Licensing and with the License Application section managers to ensure training of designated lead and support authors is completed.

- Working with $\mathrm{M} \& O$ Licensing to develop training materials and present training to support qualification of M\&O Licensing personnel, and the License Application lead and support authors.

\subsubsection{The License Application Reviewers}

The responsibilities of the License Application reviewers are defined in QAP 6.2.

\subsubsection{License Application Consulting Board}

The License Application Consulting Board will be convened to provide input to the License Application development process from persons outside the Project who are experienced and knowledgeable in the licensing process for an NRC-licensed facility. As discussed in 
Section 2.3.8, the Board will convene several times per year during License Application development and will provide advice to the Project on topics such as the development process itself, management, and regulatory interactions.

\subsection{LICENSE APPLICATION DOCUMENT TABLE OF CONTENTS}

In accordance with 10 CFR 60.21, the License Application contains general information and the Safety Analysis Report. Consistent with DG-3003, Format and Content for the License Application for the High-Level Waste Repository (NRC 1990), the planned License Application will contain general information in Chapter 1. Chapters 2 through 14 comprise the Safety Analysis Report.

The proposed basic License Application Table of Contents is contained in the Technical Guidance Document for License Application Preparation (YMP in prep.). Additional subsections may be used at the discretion of the lead authors or as provided in the Technical Guidance Document for License Application Preparation (YMP in prep.), as discussed in Appendix B to the Technical Guidance Document. Minor wording changes to the chapter, section, and subsection titles may be made at the discretion of the M\&O Licensing Manager or YMSCO Assistant Manager for Licensing without revising the License Application Management Plan, as long as the intent of the guidance in the Technical Guidance Document is not affected.

The document organization shown in the Technical Guidance Document is the result of the DOE review of NRC guidance such as that contained in DG-3003 and in NUREG-1323, License Application Review Plan for a Geologic Repository for Spent Fuel and High-Level Radioactive Waste (NRC 1995), that is applicable to the repository. It is also based on review of other NRC documents such as NUREG-0800, Standard Review Plan for the Review of Safety. Analysis Reports for Nuclear Power Plants (NRC 1987). A License Application format was selected, based on these reviews, that is believed to most clearly and effectively present a cogent safety case. Because this format does not exactly match the format in any of the NRC guidance documents, the DOE will work with the NRC to explain the format chosen and the rationale for it.

\subsection{DOCUMENT PREPARATION}

This section describes the process for the License Application preparation, including the mechanics of the preparation process as well as guidance for format, content, and style.

\subsubsection{Controlling Procedures}

The License Application will be developed by the M\&O for the DOE under the requirements of DOE/RW-0333P, Quality Assurance Requirements and Description (DOE 1997). Implementing procedures are planned to be YAP-5.1Q and YAP-5.8Q. Review of the License Application will be performed in accordance with QAP 6.2.

\subsubsection{Preparation Process}

The License Application will be developed by a multi-disciplinary M\&O project team over a period of several years. The process begins with development and approval of this Management Plan and the Technical Guidance Document by the DOE. The Management Plan provides guidance for the process of developing the License Application, while the Technical Guidance 
Document provides guidance on the required content of the License Application chapters and sections.

Development of this Management Plan will be complete prior to beginning development of the License Application. Although the Technical Guidance Document will be published prior to commencement of the License Application development, it is expected that revisions to that document will occur before and during the License Application development as repository design proceeds, site information continues to be refined, and to incorporate the effects of any changes to regulations or regulatory guidance. The Project plans to issue at least two such revisions after initial approval of the Technical Guidance Document. Each revision will include clear delineation of new guidance as well as guidance in the previous revision that has been deleted in the new revision. If the revisions affect previously developed text for the License Application, the affected lead author will revișe the draft text to incorporate guịdance changes from the Technical Guidance Document.

At the appropriate time in accordance with the License Application development schedule, the development team will be designated, and training for the team members on the License Application and its development process will occur. After an introductory meeting for the License Application development, production of the License Application chapters will begin. Actual text production will vary from chapter to chapter based on availability of information and resources. Text production will need to support the Working Draft of the License Application and acceptance reviews, which are discussed below. Detailed schedules for License Application chapter production will be developed through the Project planning process in Fiscal Year 1998.

The format of the License Application will be guided by the basic License Application Table of Contents, which is provided in the Technical Guidance Document. The Technical Guidance Document will also provide content guidance for the License Application.

The License Application will be prepared in an electronic format that is expected to allow sharing of information by all YMP personnel. The electronic format is expected to allow inclusion of tables and graphics. The format, including text processing software, will be determined in the future and promulgated to License Application authors. The document review process may also be electronic in format. If so, appropriate guidance for this review will be provided. Only the License Application Coordinator, the lead and support authors, and the licensing chapter coordinators will be able to revise the License Application text; all others will have "read only" access.

At approximately 60-day intervals during the License Application development, informal status meetings will be held. The principal purpose for these meetings will be to brief 10 to 15 YMSCO, DOE Headquarters, and M\&O senior- and mid-level managers directly involved with the License Application development on the status of the project and to provide these managers the opportunity for feedback and course correction to the License Application project team. The License Application Coordinator, selected licensing chapter coordinators, and selected lead authors or designees will attend these meetings. The room for most of these meetings will be selected to limit attendance to fewer than 30 persons to facilitate discussion among key personnel. Every third meeting will be opened to wider attendance to facilitate broader Project awareness of the License Application development status. The License Application Coordinator will start each meeting with a briefing on the License Application development project status with regard to schedule compliance. Then each designated lead author will brief the status of development of assigned chapters or sections, such briefings to be normally less than five 
minutes in length and with limited visual aids. These limits are intended to discourage managers and presenters from expending excessive resources on preparation for the briefings.

As described in Section 2.3.8, the M\&O will convene a License Application Consulting Board. This Board, planned to be comprised of three to four "experts" on the subject of successful NRC licensing of nuclear facilities, will provide advice and recommendations prior to and during the License Application development process. It is expected that the Board will convene three to four times per year and that the Board will provide recommendations in writing. The License Application Coordinator and the $\mathrm{M} \& \mathrm{O}$ Licensing Manager will review and sort the recommendations of the Board to ensure that those recommendations are provided to the appropriate lead author/section manager, and will track and coordinate disposition of the recommendations. Recommendations generically applicable to the License Application will normally be addressed by the License Application Coordinator and/or the licensing chapter coordinators. This same process will be used to track and coordinate disposition of comments pertinent to License Application development from outside organizations such as the DOE Office of Quality Assurance and the Nuclear Waste Technical Review Board.

In'view of the relatively long development period for the License Application, a Working Draft License Application will be developed to allow an interim review of the progress in document development and to provide timely incorporation of new data, revised interpretations, and correction of technical or other problems (such as integration) that may exist. The working draft will be reviewed by DOE and approved for distribution to controlled document holders.

At the appropriate time to support the submittal of License Application to the NRC, an M\&O acceptance review of the draft License Application will be performed, followed by a DOE acceptance review that will involve YMSCO and DOE Headquarters. These reviews will be coordinated by M\&O Licensing and will be timed such that the License Application will be approved by the DOE on or before the expected date the site designation is expected to take effect. After approval of the document by the OCRWM Director, M\&O Licensing will submit the License Application to the Document Control organization within Technical Publications Management for distribution within the Project.

License Application development will continue after the DOE acceptance. The DOE is required by the NWPA to submit the License Application within 90 days after the Presidential Site Recommendation takes effect. During this 90 -day period, M\&O Licensing will coordinate a presubmittal verification review by the $M \& O$ and the DOE, if, in the judgment of DOE, technical or management developments warrant a review. The purpose of this review will be to ensure that the document is current, technically correct, and consistent with Program and Project policies. In addition, updates to the DOE-accepted License Application to add additional detail and information as it becomes available will be made in a timely manner as required by 10 CFR 60 .

Planning for the License Application preparation will be a collective YMSCO and M\&́O activity. The M\&O will prepare all drafts of the License Application and its chapters. The YMSCO, the DOE Headquarters, and the M\&O will review the License Application draft documents. The DOE will review and accept the License Application for submittal to the NRC. 


\subsubsection{Qualification of the License Application Development Team Members}

All M\&O License Application lead and support authors, section managers, the M\&O Licensing Manager, the License Application Coordinator, and the licensing chapter coordinators shall be qualified and the qualification shall be documented. This qualification shall include meeting all requirements of DOE/RW-0333P, Quality Assurance Requirements and Description (DOE 1997), Section 2.2.12. With regard to requirement $H$ (indoctrination and training for a specified task), M\&O Licensing shall provide a list of designated personnel for these positions to $M \& O$ Training and Development, and M\&O Training and Development shall then ensure that all proposed lead and support authors have the following documentation of qualification:

- Documented quality assurance indoctrination.

- Written certification by management as being technically proficient in the topic or discipline for which authorship is designated.

- Documented training on the purpose of the License Application, the Technical Guidance - Document, the NRC licensing process, and this Management Plan.

The Licensing Manager shall coordinate resolution of development team member training deficiencies prior to beginning production of the License Application. They shall work with $\mathrm{M} \& \mathrm{O}$ Training and Development to ensure that appropriate training and documentation occur. If a replacement is needed for a development team member identified in this subsection or the need for an additional such team member is identified, the Licensing Manager is responsible for informing the newly designated member of the needed documentation/training, working with M\&O Training and Development to schedule the training, if applicable, and ensuring the resulting documentation is properly dispositioned. M\&O Training and Development shall provide $\mathrm{M} \& \mathrm{O}$ Licensing and the section managers a list of qualified License Application development team members before document production begins and shall thereafter inform $\mathrm{M} \& \mathrm{O}$ Licensing and the section managers in writing of any subsequent changes to the list.

Additional training on licensing related activities or documents may be conducted at the , discretion of the M\&O Licensing Manager, should changes occur in the pertinent documents. All qualified License Application development team authors will be required to complete such training.

\subsubsection{Content and Level of Detail Guidance}

Content and level of detail guidance for the License Application is provided in YMP/97-03, Technical Guidance Document for License Application Preparation (YMP in prep.).

\subsubsection{Acceptance Criteria}

Acceptance criteria for the License Application are provided in YMP/97-03.

\subsubsection{Writing and Style Guidance}

Writing and style guidance for the License Application is contained in Appendix B to the Technical Guidance Document. All authors should comply with this guidance unless authorized in writing to deviate by the $\mathrm{M} \& \mathrm{O}$ Licensing Manager. M\&O Licensing will communicate any 
approved deviations to all lead authors to encourage consistency among the License Application chapters and sections.

\subsubsection{Incorporation of Documents, Position Papers, Policies, and Other Information}

Various documents developed within and outside the Project are available to support development of the License Application. General requirements for use of such documents are provided in sections 3.4 through 3.7. Additional guidance for use of several specific, potentially important document types is provided in this section.

\subsubsection{License Application Annotated Outline}

Lead authors should review the Mined Geologic Disposal System License Application Annotated Outline, Revision 0 and Draft Revision 1 for assigned sections to ensure useful and valid information is extracted for use in the License Application. Information obtained from the Mined Geologic Disposal System License Application Annotated Outline is subject to the requirements provided in sections 3.4 through 3.7 .

\subsubsection{Operating Experience Information}

Operating experience information is information systematically obtained and analyzed for lessons learned to prevent problems, which have occurred elsewhere, from occurring at the repository. Examples of such information include descriptions of waste handling events and operator errors obtained from sources such as other DOE projects, commercial nuclear facilities, and mining activities.

Each lead author should briefly describe how such information has been used in the activities relevant to assigned text. This discussion would normally not exceed a sentence or two for a topic. The operating experience discussion should include a short general description of how operating experience information was used to support a broad area, e.g., repository design or the radiation protection program, and a more specific discussion as applicable on how operating experience was used in more specific areas, e.g., design of a specific piece of equipment. Fơr example: "Design of the (whatever) equipment reflects lessons learned from (a specified document or event) in that (explain how the review of the operating experience item affected the design of the equipment)." The License Application may also contain a summary section that would describe how operating experience information has been used in support of repository design and operations concepts. This summary section will describe in general how the information was obtained and how its relevance was determined.

The responsibility for obtaining and using operating experience information will be specified in other Project documents. This Management Plan only provides for how the use of such information is to be discussed in the License Application. All the License Application lead authors will ensure familiarity with how operating experience is used to support the subjects of assigned chapters and sections to include them in the License Application discussions.

\subsubsection{Topical Reports}

Topical reports are intended to obtain NRC acceptance of approaches to resolving certain key issues. This acceptance, in accordance with the NRC procedures for reviewing topical reports, would be provided in conjunction with a preliminary evaluation report to be issued by the NRC 
that could be referenced in the License Application. The NRC-accepted approach could be used in support of the License Application and hopefully could reduce the time required to both develop the License Application case for resolution of the issue and the NRC time required to review the issue as part of the License Application review (the NRC reserves the right to readdress any issues covered in the topical report should new, relevant information indicate the need to do so). If the topical report on an issue provides the approach to addressing an issue rather than the resolution of the issue, follow-on reports may be used to apply the approach described in the topical report to actually address or resolve the issue. The License Application lead authors should, to the extent feasible, refer in the License Application to NRC-accepted topical reports and their follow-on reports in lieu of providing detailed discussions of the resolution approach in the License Application. Reference should be made to the NRC document that has accepted the topical report, and any context of or limitations on that acceptance should be described.

Topical reports developed and submitted to the NRC but not yet accepted may also be referenced in the License Application. Referencing such a document is no different from referencing any other technical document that has not been specifically reviewed and accepted by the NRC.

\subsubsection{Other Documents}

Other Project documents, such as position papers, technical reports, or systems studies may be referenced or discussed in the License Application, subject to the requirements of sections 3.4 through 3.7. The substance of these documents and their significance to licensing should be addressed in the License Application. Documents developed outside the Project, such as industry standards and technical reports, may also be referenced or discussed, subject to the same requirements. Use of such documents will be as specified in the Technical Guidance Document; additional documents beyond those specified may be referenced at the discretion of the lead authors.

\subsubsection{License Application Consulting Board}

The $\mathrm{M} \& \mathrm{O}$ will convene a License Application Consulting Board to support the development of the License Application. Its intent will be to provide input to the License Application development process from "experts" (such as ex-NRC staff) in the field of obtaining NRC licenses for nuclear facilities. These individuals would not be employed by the repository project except in this consulting role. The Board will be constituted such that it can provide advice on a wide spectrum of License Application topics, such as the development process, management, and regulatory interactions. It will also include an industry licensing expert. Though the Board will not primarily be concerned with specific technical and other issues, it is expected that Board members will possess expertise to review and provide advice on broad technical issues that may impact licensing.

It is expected that the Board would be asked to convene three to four times per year and to provide its recommendations in writing. The Board may be asked to review the working and/or acceptance drafts of the License Application. The $\mathrm{M} \& \mathrm{O}$ will request some topics be reviewed by the Board. The Board may also independently determine topics for which its consideration and advice would be helpful. The License Application Coordinator and the M\&O Licensing Manager will review, track, and disposition the recommendations of the Board. 
The M\&O will plan to convene the Board for the first time early in FY 1999. The Board will not provide advice to DOE. It will advise and support the $\mathrm{M} \& \mathrm{O}$ under individual consulting agreements.

The M\&O Licensing Manager will budget for the services of the Board and will coordinate the effort to identify and obtain the services of highly experienced and qualified persons to serve as Board members.

\section{$2.4 \quad$ REVIEWS}

The subsections that follow describe how reviews of the License Application are to be conducted. There will be six basic review types:

$\therefore$ Reviews that occur during the initial development of the License Application (Section 2.4.1).

- $\quad \mathrm{M} \& O$ acceptance review (Section 2.4.2).

- DOE acceptance review (Section 2.4.3).

- Verification review to support submittal of the License Application to the NRC (Section 2.4.4).

- Reviews to support post-acceptance or post-submittal License Application updates (Section 2.4.5).

\subsubsection{Reviews During License Application Development}

In view of the relatively long development period for the License Application, a Working Draft License Application will be developed to allow an interim review of both the progress in document development and to provide timely correction of technical or other problems that may exist. The working draft will contain the document number of the License Application and will be labeled as "Draft Revision A."

The working draft will be reviewed by the $\mathrm{M} \& \mathrm{O}$ and by the DOE in accordance with QAP 6.2 and YAP-30.12, Publications Review, Approval, and Distribution. M\&O Licensing will coordinate the review under the direction of the YMSCO Assistant Manager for Licensing. Section Managers will ensure that chapters and sections are reviewed and that comments are addressed and resolved in accordance with the License Application development schedule. The $\mathrm{M} \& \mathrm{O}$ review will include a review by $\mathrm{M} \& \mathrm{O}$ Licensing for content and consistency. Reviewers will be reminded of the incomplete nature of the document at the time of review and will be asked to comment in that context. Upon review and incorporation of comments and concurrence by the DOE, the Working Draft License Application will be issued to designated controlled document holders.

It is also expected that the section managers will ensure that periodic informal, in-house reviews of respective License Application sections are performed during the writing process. These reviews should verify the technical accuracy of the document, as well as the correctness of the content and format per the Technical Guidance Document. These reviews also should focus on the presentation of data and analyses to reach a conclusion or to present a compelling argument. 
These reviews should verify that data used in the License Application sections under review meet applicable quality assurance requirements. In addition, $M \& O$ management will review the License Application sections informally during the License Application development process. The Licensing Chapter Coordinator for each chapter will also review the progress of chapter development periodically and will provide licensing perspective to help ensure that the chapter and the sections within the chapter are being developed in a manner supportive of making the licensing case for that chapter. The reviewer qualification requirements referenced in Section 2.4.6 do not apply to reviews discussed in this paragraph.

\subsubsection{M\&O Acceptance Review}

An M\&O acceptance review of the License Application will be performed to support submittal of the License Application to DOE for approval and to NRC in accordance with the NWPA, this Management Plan, and the License Application development schedule. This review will be timed such that it and the DOE acceptance review (see Section 2.4.3) will be completed prior to the effective date of site designation. The License Application development process and other Project activities will be timed such that the License Application that goes into this review will be considered to make an effective safety case for authorization to construct the repository.

CRWMS M\&O reviewers will be chosen by CRWMS M\&O management direction based on qualifications and technical competence in the subject area. M\&O Licensing will review the draft License Application, as will the $M \& O$ legal staff. M\&O Licensing will provide written instructions for the review prior to the beginning of the review and will coordinate the review. The License Application Section managers will ensure that for each chapter and section assigned to them, draft text is compiled by the respective lead authors and provided to $\mathrm{M} \& \mathrm{O}$ Licensing for transmittal to identified $M \& O$ reviewers. They will ensure that comments received on their assigned sections are resolved. Review criteria will include those in QAP 6.2, as appropriate, and the additional criteria below.

- Is the safety case in the License Application easily understood, or should it be clarified or reorganized to be more consistent or logical?

- Is the demonstration of compliance with waste containment and isolation requirements easily understood?

- Does the License Application comply with criteria in NUREG-1323: License Application Review Plan for a Geologic Repository for Spent Nuclear Fuel and High-Level Radioactive Waste (NRC 1995)?

- Are all supporting details necessary and sufficient?

- Do the graphics such as maps, tables, and graphs specify the minimum information required and are they properly referenced and interpreted in the text?

- Do the graphics contain the appropriate information such that they support the text as referenced (i.e., do they contain and clearly illustrate the supporting data)?

- Are the assumptions, interpretations, data and references presented clearly so that an outside reviewer can reach a similar conclusion independently? 
- Is the qualification status of the inputs identified? Have unqualified data directly relied upon to address safety and waste isolation issues been qualified?

- Are alternative interpretations of data and alternate conceptual models discussed and evaluated?

- Are anomalous data discussed and evaluated?

- Have the computer programs referenced in the License Application been qualified as required by DOE/RW-0333P, Quality Assurance Requirements and Description (DOE 1997), Supplement I?

- . Are electronic versions of calculations properly documented? $\therefore$

- Are necessary tolerances and parameters provided for data?

- Is the License Application consistent with existing regulatory and other Project

- commitments? Have commitments applicable to the License Application been appropriately addressed?

- If the License Application makes any commitment or addresses a topic of regulatory interest, is it consistent with OCRWM and Project policy? Are all commitments clearly identified and captured in the Project's commitment tracking process?

- Does the License Application adequately address all applicable regulatory requirements in a traceable manner?

- Are the applicable requirements and acceptance criteria of the Technical Guidance Document for License Application Preparation (YMP in prep.) adequately identified and addressed in the License Application?

Technical and policy comments are to be made only on comment forms to be provided, not ơn the text pages. Comments must be legible. Editorial comments requiring no response may be noted in the body of the text for assistance to the lead or support author who will use discretion in incorporating such comments.

$\mathrm{M} \& \mathrm{O}$ section managers and lead authors will coordinate resolution and incorporation of the comments. The License Application section manager will coordinate comment resolution meetings as necessary. Records of the review will be assembled by M\&O Licensing and submitted to the Records Processing Center in Las Vegas.

\subsubsection{DOE Acceptance Review}

The DOE, the owner of the License Application, will review both the draft chapters of the License Application prepared by the CRWMS M\&O and the completed document on the agreed upon date, and will issue the License Application as a DOE document. The DOE review of the License Application draft chapters and sections will be conducted in accordance with QAP 6.2. Review criteria for this review will include those in QAP 6.2 as appropriate, and those that follow: 
- Is the safety case in the License Application easily understood, or should it be clarified or reorganized to be more consistent or logical?

- Is the demonstration of compliance with waste containment and isolation requirements easily understood?

- Does the License Application comply with criteria in NUREG-1323: License Application Review Plan for a Geologic Repository for Spent Nuclear Fuel and High-Level Radioactive Waste (NRC 1995)?

- Are all supporting details necessary and sufficient?

$\because \quad$ Do the graphics such as maps, tables, and graphs specify the minimum information required ànd are they properly referenced and interpreted in the text?

- Do the graphics contain the appropriate information such that they support the text as referenced (i.e., do they contain and clearly illustrate the supporting data)?

- Are the assumptions, interpretations, data and references presented clearly so that an outside reviewer can reach a similar conclusion independently?

- Is the qualification status of the inputs identified? Have unqualified data directly relied upon to address safety and waste isolation issues been qualified?

- Are alternative interpretations of data and alternate conceptual models discussed and evaluated?

- Are anomalous data discussed and evaluated?

- Have the computer programs referenced in the License Application been qualified as required by DOE/RW-0333P, Quality Assurance Requirements and Description (DOE 1997) Supplement I?

- Are electronic versions of calculations properly documented?

- Are necessary tolerances and parameters provided for data?

- Is the License Application consistent with existing regulatory and other Project commitments? Have commitments applicable to the License Application been appropriately addressed?

- If the License Application makes any commitment or addresses a topic of regulatory interest, is it consistent with OCRWM and Project policy? Are all commitments clearly identified and captured in the Project's commitment tracking process?

- Does the License Application adequately address all applicable regulatory requirements in a traceable manner?

- Are the applicable requirements and acceptance criteria of the Technical Guidance Document adequately identified and addressed in the License Application? 
The YMSCO Assistant Manager for Licensing will publish written instructions for the review prior to initiation of the review, including designation of proposed DOE reviewers. Qualification of reviewers is referenced in Section 2.4.6. The review will include a review by DOE Headquarters. In addition, a review by the DOE Office of the General Counsel and other nonOCRWM DOE organizations (as designated by the YMSCO Assistant Manager for Licensing) will occur at the same time. The YMSCO Assistant Manger for Licensing will coordinate the distribution of chapters/sections for review and comment within the DOE and organizations outside the CRWMS M\&O structure, unless the DOE delegates this responsibility to M\&O Licensing. Records of the review will be assembled by the DOE or M\&O Licensing and submitted to the Records Processing Center in Las Vegas.

M\&O section managers and lead authors will coordinate resolution and incorporation of the comments. The Licenșe Appliçation șection manager will çoordinate comment resolution meetiings as necessary.

After the License Application has been reviewed and comments have been appropriately incorporated, M\&O Licensing will submit the document for DOE acceptance. When that acceptance is obtained, $M \& O$ Licensing will coordinate distributing the complete License Application document within the Project as Revision 0. A YAP-30.12 review will be conducted to obtain approval for external release of the License Application.

\subsubsection{Pre-Submittal Verification}

If, in the judgment of DOE, technical or management developments warrant a review, a verification review of the License Application will be performed. The purpose of this review is to verify that the information in the License Application remains technically correct and is in accordance with Program and Project policy. The YMSCO Assistant Manager for Licensing will designate in writing the reviewers for this review prior to the site designation becoming effective. The list of reviewers may include reviewers from YMSCO, DOE Headquarters, the M\&O, the Management and Technical Services Contractor, and the United States Geological Survey. The review will be conducted in accordance with QAP 6.2. It will have specific review criteria to focus the review and ensure it can be completed and comments addressed in the 30-day period immediately following the date that the site designation is effective. A YAP-30.12 review will be conducted to obtain approval for external release of the License Application. M\&O Licensing will then coordinate production of the License Application to be submitted and will submit the License Application to the DOE for signature by the designated signature authority. This version will be Revision 1. Once the signature authority approves the License Application, it will be submitted to the NRC, and copies will be distributed as appropriate.

\subsubsection{Post-Submittal Updates}

After site designation and the License Application submittal to the NRC, the License Application may need to be revised to incorporate additional or new information or to address NRC requests for additional information. Information appropriate for inclusion in an update would include new information that affects the licensing case made in the License Application. It would also include confirmatory information that addresses requirements for additional information as indicated in Section 11.11 of the License Application. Also, in order for the NRC to consider issuing a license to receive and possess radioactive materials, 10 CFR 60.24 requires the DOE to update the License Application "in a timely manner" to permit the NRC to review additional information obtained during construction, results of confirmatory studies, and other information 
bearing on license issuance not available at the time of original submittal of the License Application. These updates will be reviewed in accordance with QAP 6.2 and will be on a "change page" basis. This process, with proper planning and Technical Guidance Document guidance, is expected to result in a satisfactory license application to receive and possess radioactive waste at the proper time in the construction process. The License Application originally submitted for construction authorization, updated after original submittal to reflect constantly supplemental site and performance information, will evolve into the updated license application to receive and possess radioactive materials.

This version of the License Application will be reviewed in the same manner as previous updates and using the same controls. After approval by the DOE and when the conditions stated in 10 CFR 60 have been met, this version will be submitted to the NRC to seek the license to receive and possess radioactive materials. A future revision to the Management Plan will provide additional guidance for development and submittal of the updated application for a license to receive and possess radioactive materials.

After the license to receive and possess radioactive materials is issued pursuant to 10 CFR 60.41, updates to the Safety Analysis Report portion of the License Application will continue to occur at least annually, or more frequently if considered appropriate by the YMSCO Assistant Manager for Licensing.

\subsubsection{Qualifications of Reviewers}

All DOE, M\&O, Management and Technical Services Contractor, and United States Geological Survey reviewers for the formal reviews specified in section 2.4 shall meet the requirements in section 5.1.2 of QAP 6.2. 


\subsection{PROJECT MANAGEMENT AND CONTROL}

This chapter describes the management and administrative process that will govern development of the License Application.

\subsection{ESTABLISHMENT AND MAINTENANCE OF THE PROJECT DEVELOPMENT} TEAM

At least 180 days prior to scheduled commencement of the License Application development project, M\&O Licensing shall have identified and obtained approval from the DOE Assistant Manager for Licensing of the section managers for the License Application who are responsible for development of assigned chapters and sections.

At leàst 60 days prior to scheduled commencement of the License Application development project, the tentative list of lead and support authors shall have been designated by the section managers and published by M\&O Licensing. The selection of lead authors and contributing authors is at the discretion of the section managers, as long as the qualification requirements of Section 2.3.3 are met. However, to the extent feasible, these individuals should have substantial Project experience and strong written communications skills.

\subsection{COMMITMENT MANAGEMENT AND TRACKING}

Commitments are written "promises" made by the Project to outside organizations. The Project has generally clearly delineated commitments in communications with the outside organization to whom the commitment is made. Commitments made by the Project to outside organizations, especially the NRC and EPA, could become a licensing issue prior to or after the License Application is submitted. In addition, it is considered prudent to perform a review of past correspondence that may have resulted in de facto commitments or that may have not been captured in the commitment tracking data base. As part of the License Application development effort, the Project will review Project records for past commitments that relate to licensing issues. M\&O Licensing will coordinate identifying the commitments and will ensure that they are dispositioned by Project management and are entered into the commitment tracking data base to be maintained by $M \& O$ Licensing. Each commitment will be linked to the appropriate section(s) of the License Application. Disposition will include determinations whether commitments apply to licensing, whether the Project has plans in place to appropriately meet the commitment, and determination of corrective action where the commitment may not be met. The data base will be maintained throughout the life of the repository through closure to keep track of commitments and actions taken and/or planned to address the commitments. M\&O management will review the data base and ensure that failure to properly address commitments does not delay the License Application submittal and docketing or construction authorization approval.

\section{DECISION MANAGEMENT AND TRACKING}

The License Application, required to be filed in close proximity to the date the site designation is effective, is the primary focus of Project resources for the period from completion of the 1998 Viability Assessment to issuance of the construction authorization by the NRC. If the President recommends the Yucca Mountain site for development, the success of the Project over that period will be determined by the successful docketing of the License Application and subsequent NRC issuance of the construction authorization. Given the importance of this effort and the scrutiny to which it will be subjected, it is necessary that all significant Project management, 
technical, and policy decisions with regard to this effort be made in a careful, controlled manner; and that all such decisions be documented.

Decisions made with regard to the License Application will be documented in accordance with DOE procedures for decision documentation that will be in place before license application development begins. The YMSCO Assistant Manager for Licensing is responsible for developing a plan for documenting decisions and for managing the implementation and control ' of the process to be developed. Decision documentation procedures will be incorporated into the License Application by reference.

\subsection{REQUIREMENTS FOR REFERENCES, DATA, AND ASSUMPTIONS}

The License Application will reference many documents, generated both within the Project and outside the Project. The referencing of a document in the License Application does not by itself create an explicit Quality assurance or other control requirement on the reference. Lead and support authors are responsible for the selection of technically valid and defensible references and must recognize the likelihood that many of the License Application references will be challenged at various stages of document development and during the licensing process. Therefore, references must not only be valid but must be capable of being demonstrated to be valid. In addition, lead and support authors are responsible for ensuring that references in assigned chapters and sections meet applicable requirements discussed in Section 3.5.

The License Application will also contain large amounts of used or referenced data, which will be subject to identical considerations discussed in the previous paragraph and which must be documented as discussed in Section 3.5.

Assumptions, unproven assertions upon which conclusions may be based, which are included in the License Application must be clearly identified as such. Conclusions based wholly or partly on assumptions must be presented in a manner that will show the extent to which they depend on the assumption and the sensitivity of the conclusion to the accuracy or validity of the assumption. As unproven assertions, assumptions are inherently open to question and challenge; therefore, lead and support authors should consider alternatives. Where assumptions are necessary, the assumption should be justified. In addition, when feasible, the assumption should be supported with sensitivity analyses that show that the associated conclusions are relatively insensitive to the accuracy of the assumption. Authors should not state conclusions for which there are no supporting technical bases.

As discussed in greater depth in the Technical Guidance Document, the License Application must also include documentation of alternative models and interpretations of data that were not used in the licensing case. Reasons for not choosing the alternatives should be provided in this discussion.

\subsection{IDENTIFICATION AND TRACEABILITY OF REFERENCES, DATA, AND} ASSUMPTIONS

All references in the License Application must be available either as an OCRWM record in the OCRWM Records System, as a document in an OCRWM Technical Information Center, or in the public domain and available at or through a public university library or the NRC reading room. The OCRWM Records Management System is the controlled source of OCRWMgenerated information, and any reference material that is an OCRWM record is to be verified 
against this source to ensure that (1) it has been captured in the reference system, (2) the copy of the reference used is an exact duplicate of the copy in the record system, and (3) it has not been supplemented or superseded. License Application authors are responsible for providing copies of references to the Technical Information Center or the Records Processing Center. References that are records in accordance with AP-17.1Q (and are therefore not copyrighted) shall be provided to the Records Processing Center. In accordance with AP-17.1Q, a list of copyrighted documents shall be provided to the Technical Information Center, which will obtain copies and copyright clearances. Appropriate guidance for copyrighted clearance of electronic media references will be developed.

Data provided in the License Application shall include reference cites to the data source. Assumptions included in the License Application shall be clearly identified as such.

Data collected, acquired, or developed by the Project that is used and/or referenced in the 'License Application must have been submitted for inclusion in the GENISES and the Reference Information Base if required by Project procedures. Reference documents that are not records and are not copyrighted shall also be provided to the Technical Information Center. Lead and support authors are responsible for ensuring all such information used or referenced in chapters/sections has been properly submitted for inclusion in these data bases as required by procedure. A data tracking number must be included with the reference.

\subsection{QUALITY ASSURANCE REQUIREMENTS}

The License Application writing activity has been determined to be a quality affecting activity. Primarily, this designation is based on the importance of the License Application to the successful licensing of the proposed repository and on the extremely large amount of information that will be presented in the License Application.

Implementing procedures under which the License Application will be developed and reviewed are listed in Section 2.3.1.

\subsection{RECORDS}

The License Application, as noted in Section 2.3.1, will be controlled under the DOE quality assurance procedures. Records generated during preparation of the License Application will be controlled in accordance with AP-17.1Q and DOE/RW-0333P.

There are no quality assurance or inclusionary records generated by this plan. 


\subsection{SCHEDULE AND MILESTONES FOR LICENSE APPLICATION DEVELOPMENT}

Yucca Mountain Site Characterization Project planning documents will provide the schedule for License Application development. 


\subsection{REFERENCES}

\subsection{REFERENCES}

DOE (U.S. Department of Energy) 1997. Quality Assurance Requirements and Description, DOE/RW0333P. Rev. 07. Washington, D.C.: Author.

NRC (U. S. Nuclear Regulatory Commission) 1987. Standard Review Plan for the Review of Safety Analysis Reports for Nuclear Power Plants. NUREG-0800. Washington, D.C.: U.S. Government Printing Office.

NRC 1990. Format and Content for the License Application for the High-Level Waste Repository. DG3003. Washington, D.C.: U. S. Government Printing Office.

$\therefore \quad \therefore$

NRC 1995. License Application Review Plan for a Geologic Repository for Spent Fuel and High-Level Radioactive Waste. NUREG-1323. Washington, D.C.: U. S. Government Printing Office.

YMP (in prop.). Technical Guidance Document for License Application Preparation. YMP/97-03. Las Vegas, Nevada: Yucca Mountain Site Characterization Office.

YMP (in prep.). License Application Plan.

\subsection{CODES AND STANDARDS}

10 CFR 60. Disposal of High-Level Radioactive Wastes in Geologic Repositories, LWR Edition. Washington, DC: U.S. Government Printing Office.

Nuclear Waste Policy Act of 1982, as amended. Public Law 97-425, 42 U.S.C. 10101-10226.

Washington, DC: U. S. Government Printing Office.

\subsection{PROCEDURES}

AP-17.1Q, Record Source Responsibilities for Inclusionary Records.

QAP-2-1, Indoctrination and Training.

QAP 6.2, Document Review.

YAP-5.1Q, Submittal of Documents for Development, Change, Review, and Deliverable Acceptance.

YAP-5.8Q, Technical Document Preparation.

YAP-30.12, Publications Review, Approval and Distribution. 


\section{APPENDIX A}

\section{ACRONYMS AND ABBREVIATIONS}

DOE * U.S. Department of Energy

GENISES Geographic Nodal Information Study and Evaluation System

M\&O Management and Operating Contractor

NRC U.S. Nuclear Regulatory Commission

NWPA Nuclear Waste Policy Act of 1982, as amended

OĆRWṂ Office of Civilian Radioactive Waste Management

YMP - Yucca Mountain Site Characterization Project

YMSCO Yucca Mountain Site Characterization Office 
Enclosure 2

Deliverable Acceptance Review Request 
Enclosure 3

Participant Planning Sheets 
Signatures on this document represent signers' knowledge that the applicable procedures have been read, understood, and complied with.
1. CR No.: Mod.:
3. Change Type:

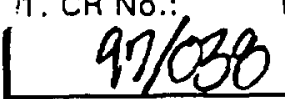
2. Original's Control No.:
Mido $97-025$
$\square \begin{aligned} & \text { Technical } \\ & \text { Cost }\end{aligned}$
Project WBS
D Other
Schedule
4. Change Control Level:
$\square$ Level 1 PBCCB $\square$ Level 2 CCB Baseline
Level 2 CCB Controlled
5. Priority:
$\square$ Immediate
¿] Urgent
$\square$ Routine

6. Title of Change Request:

Modify LA Plan deliverable descriptions and completion criteria (SL300M3A \& SL300M3B) and add LA Management Plan and LA Technical Guidance Document deliverables.

7. Identify the Documents/Drawings Affected by this CR:

See Documentation Continuation

\begin{tabular}{|c|c|c|c|c|c|c|c|}
\hline Document Number/Title & $\begin{array}{l}\text { Current } \\
\text { Rev/ICN } \\
\end{array}$ & A/R/D & QA Class & $\begin{array}{l}\text { Resulting } \\
\text { Rev/ICN }\end{array}$ & $\begin{array}{c}\text { Design } \\
\text { Package } \\
\end{array}$ & $\begin{array}{c}\text { Job } \\
\text { Package } \\
\end{array}$ & Configuration Item Identifier \\
\hline YMP/CM-0015, PCSB & $\mathbf{N} / \mathbf{A}$ & $\mathbf{R}$ & $\mathbf{N} / \mathbf{A}$ & $\mathbf{N} / \mathbf{A}$ & N/A & $\mathbf{N} / \mathbf{A}$ & N/A \\
\hline & & & & & & - & \\
\hline & & & & & & & \\
\hline . & & & & & & & \\
\hline
\end{tabular}

8. List Attachments [page number(s) and page count(s)]

A) Impact Analysis Record

B) Concur:a.: s: Snature Sheit

C) Redlined Participant Flanning Sheet
9. Identify Related CR, CAR, BCP, DAR, etc.: N/A

10. Identify Project WBS No.(s) at the Level Affected by the Change: i.2.5.2.4

11. Description of the Change Request:

Clarified the acceptance criteria for the LA Plan. Added deliverables for the LA Management Plan and LA Technical

Guidance Document. Indicated that the LA Plan and LA Technical Guidance Document to be delivered 9/30/97 will be draft instead of final.

12. Justification for Change and Priority Type; Summarize the Impact if Change is not Approved:

Clarification requested by the DOE. Priority "Urgent" to obtain approval before deliverable due date.

See Documentation Continuation Page

13. Originator:

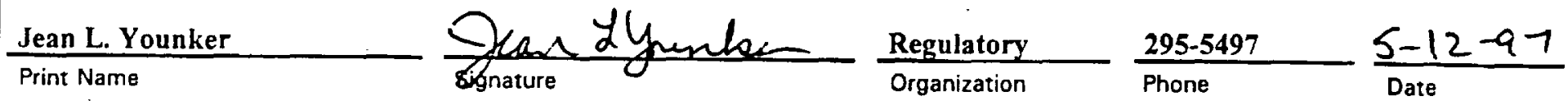

14. AM/Director Concurrence:

Stephan J. Brocoum

Print Name
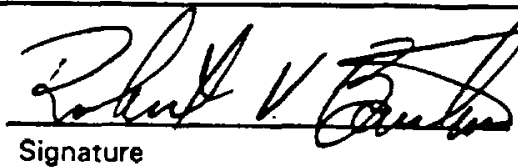

Licensing

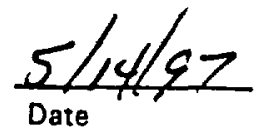

15. This CR has been Accepted or Rejected by the CCB Secretary as indicated below:

$\checkmark$ Accepted $\square$ Rejected




$$
\begin{aligned}
& \text { YMP-219-R1 } \\
& \text { O4/16/97 }
\end{aligned}
$$

YUCCA MOUNTAIN SITE CHARACTERIZATION PROJECT COST/SCHEDULE BASELINE CHANGE PROPOSAL

CONCURRENCE SIGNATURE SHEET
Page 1 of 1

2 CR No.:

3 Originator's Control No.:

'Modify LA Plan deliverable descriptions and completion criteria (SL300M3A \& SL300M3B) and add LA Management Plan and LA Technical Guidance Document deliverables.

4 TPO Concurrence:

CRWMS M\&O

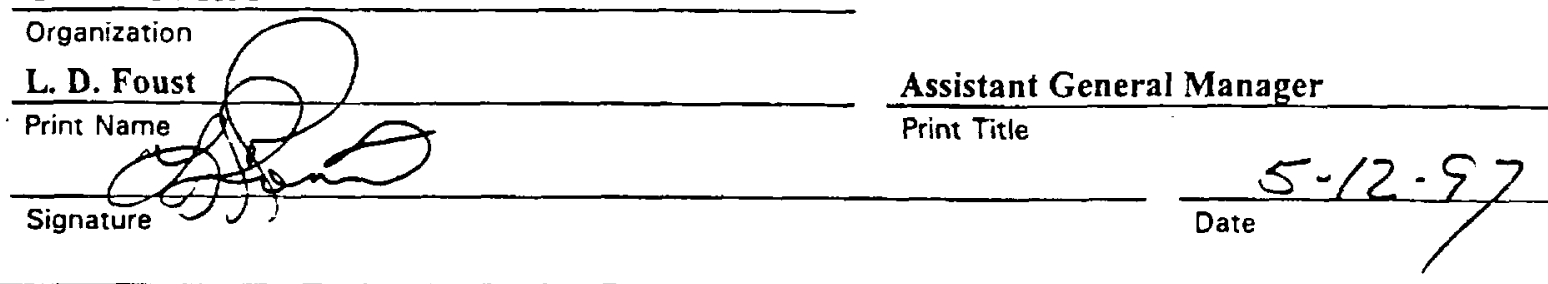

5 TPO Concurrence:

$$
\text { NA }
$$

Organization

Print Name

Print Title

Signature

Dare

6 AMAAM Concurrence:

Is Contract/WAD Revision Required?

Yes

No

Is Contract Modification Required? $\square$ Yes $叉$ No Is AFP Change Required?

Jerri J. Adams

AM Administration and Asset Management

Print Name

Print Title

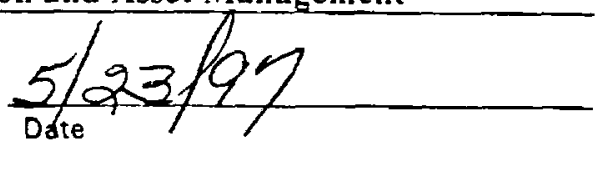

7 Affected AM/Director Concurrence:

N/A

Print Name

Print Title

Signature

Date

8 Responsible AM/Director Concurrence:

Stephan J. Brocoum

Print Name

Rot

Signature

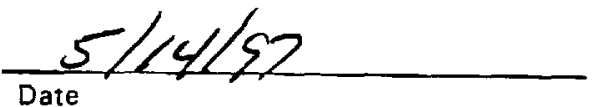

9 OPC Concurrence:

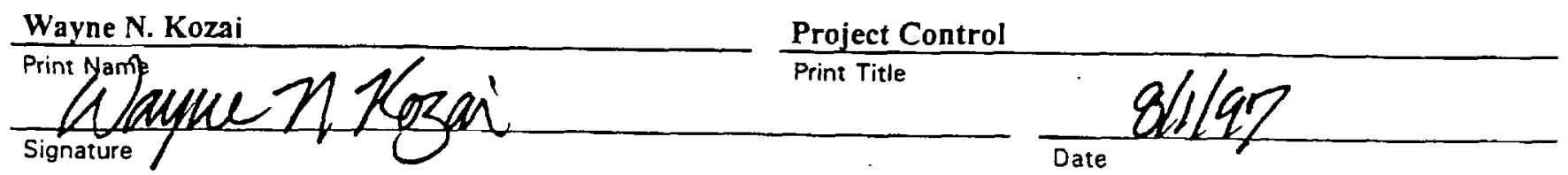

Exhibit YAP .30.47.1 
YMP.215.R1

$09 / 18 / 95$
YUCCA MOUNTAIN SITE CHARACTERIZATION PROJECT

IMPACT ANALYSIS RECORDICCB EVALUATION

\begin{tabular}{|l|l|c|}
\hline CR No.: $\quad$ Mod: & $\begin{array}{l}\text { CR Title: } \\
\text { Modify LA Plan deliverable descriptions and completion criteria } \\
\text { (SL300M3A \& SL300M3B) \& add LAMP \& LA TGD deliverables }\end{array}$ & $\begin{array}{c}\text { Priority: } \square \text { Immediate } \\
\square \text { Urgent } \\
\square \text { Routine }\end{array}$ \\
\hline
\end{tabular}

Signatures on this document represent signers' knowledge that the applicable procedures have been read, understood, and complied with.

\section{SECTION I. CR TECHNICAL COST AND SCHEDULE IMPACT ANALYSIS}

A. Technical See Documentation Continuation Page Check the items affected by the proposed change and provide supporting impact analysis for each discipline/activity item. Use the Documentation Continuation Page for impact analysis, if necessary. Identify potential impacts that include, but are not limited to, the following:

$\square$ Item Important to Safety (IITS)

$\square$ Item Important to Waste Isolation (IITWI)

$\square$ Environment, Safety and Health

$\square$ Physical Interface Control

$\square$ Construction

$\square$ Design Requirements Documents| Specifications/Drawings

$\square$ Basis for Design/Determination of Importance Evaluation

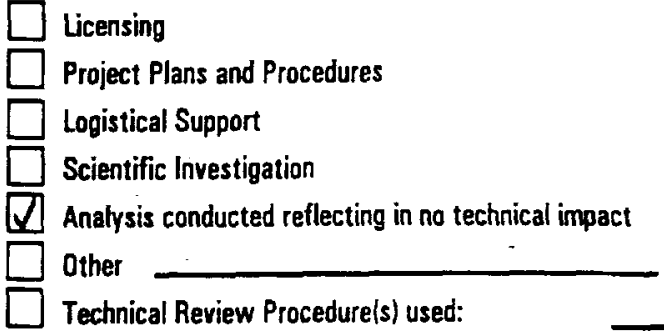

Technical Review Procedure(s) used:

B. Cost, Schedule or Workscope

Summarize the Cost/Schedule impacts associated with this change.

Clarified the acceptance criteria for the LA Plan. Added deliverables for the LA Management Plan and LA Technical Guidance Document. Indicated that the LA Plan and LA Technical Guidance Document to be delivered $9 / 30 / 97$ will be ) draft instead of final.

C. Other Documents Affected

List other documents potentially affected by approval of this change, but not changed by this change.

None

Originator:

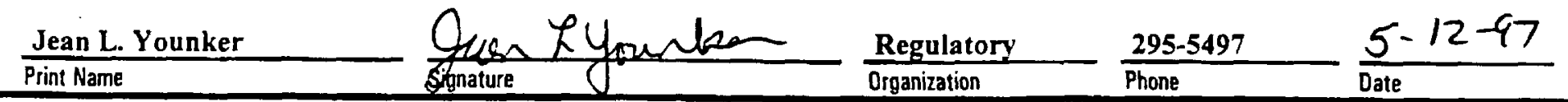

SECTION II. CCB EVALUATION AND RECOMMENDATION

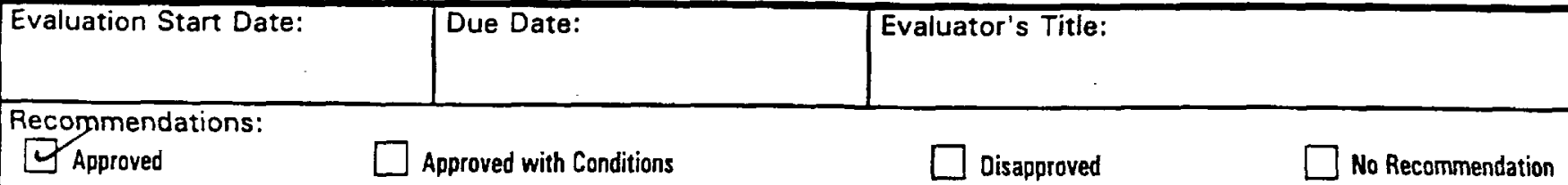

Comments:
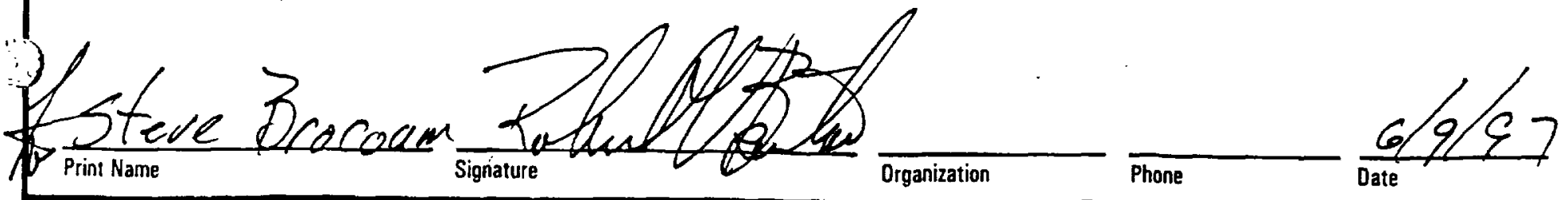


\section{Enclosure 1}

Management Plan for the Development of the License Application for a High-Level Waste Repository at Yucca Mountain 


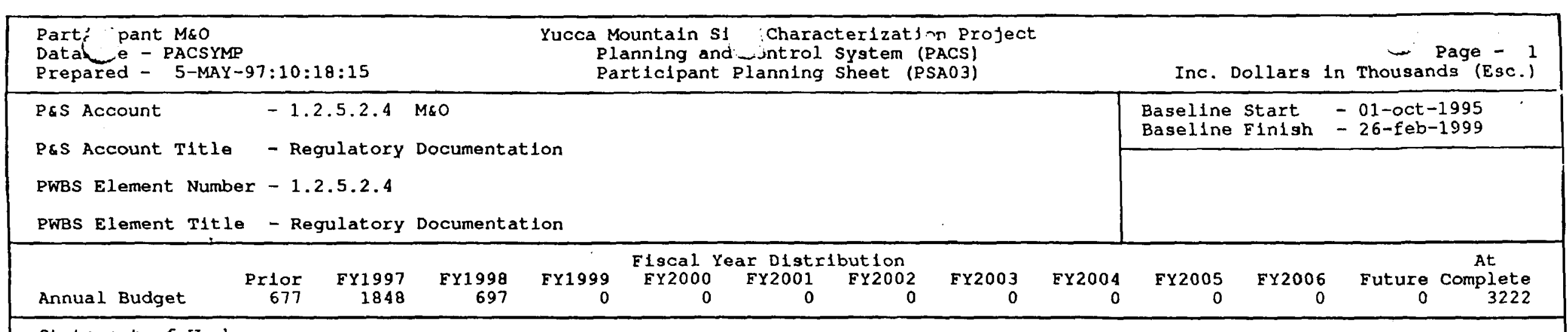

Statement of Work

Support YMSCO in preparation and development of Semi-Annual site characterization Progress Reports Nos 15 , 16 and 1nit1ate

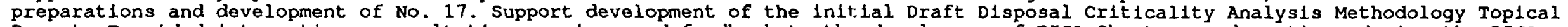

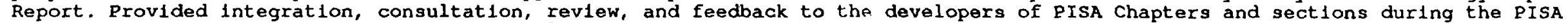
development. Provide review of Draft Material to assess compliances witi PISA Management Plan Guldance, etc., and begln the consolidation and integration of the PISA Chapters into the overall PISA Document.

Bulld upon the PISA Management Plan and provide format and content requirements, acceptance criterla, schedules and license

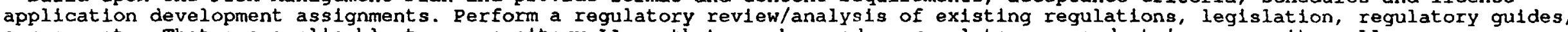
nuregs, etc. That are applicable to a repository LA or that can be used as regulatory precedent in a repository LA.

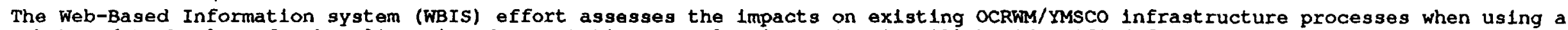
Web-based technology for key licensing documentation. Evaluation criteria will be identified for which information will be gathered and assessments made in order to provide YMSco with recommendations. Key process questions to be assessed include

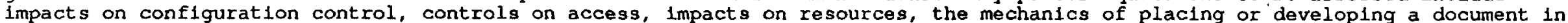
this environment and impacts on the hardware/software (HW/SW) infrastructure. The effort consists of two phases.

Phase I Prototype Test

1. Preparations:

The HW/SW environment will be established: process descriptions will be developed; requirements will be developed; and evaluation criterla will be developed.

2. M\&O Management Plan

An M\&O Management Plan will be developed and submltted to YMsco for acceptance.

3. Part 1: Placing a Document

While Placing a document in this environment (converting the document to Hyper Text Markup Language (HTML), identifying references/citations to be linked to support information, identifying the sources of the support information, establishing the links, and complying with the requirements for conflguration and access control) information will be gathered for use in the assessment against all evaluation criterla. The information will be asgessed, recommendations developed, and a letter report submitted to YMSCO for their review, consideration and direction.

4. Part 2: Developing a

4. Part 2: Developling a Document

While Developing a document in this environment (writing and reviewing a subsection of the pisa, identifying

references/citations to be linked to supporting information, identifying sources of the support information, establishing the

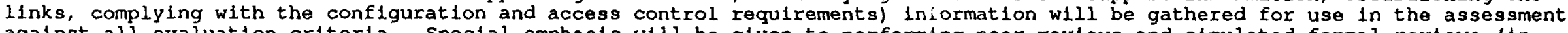
agalnst all evaluation criterla. Special emphasis will be given to performing peer reviews and simulated formal reviews (1n accordance with QAP 6.2). The information gathered will be assessed, recommendations developed, and a letter report will be submitted to YMSCO for their review, consideration, and direction.

Phase II Potential Implementation

1. Based on direction received from YMSCO, Phase II w1ll be scoped and the WBIS MsO Management Plan revised and submitted to Yisco for acceptance.

2. Per the revised Management Plan, the activities will be implemented.

Summary Account Title

TR524CO FY1995 Carryover

TR524E.B010 Regulatory Documentation

TR524FA1 Support Draft Critlcality Control Toplcal Rpt. Dvl 
TR524 Regulatory Documentation (continued)

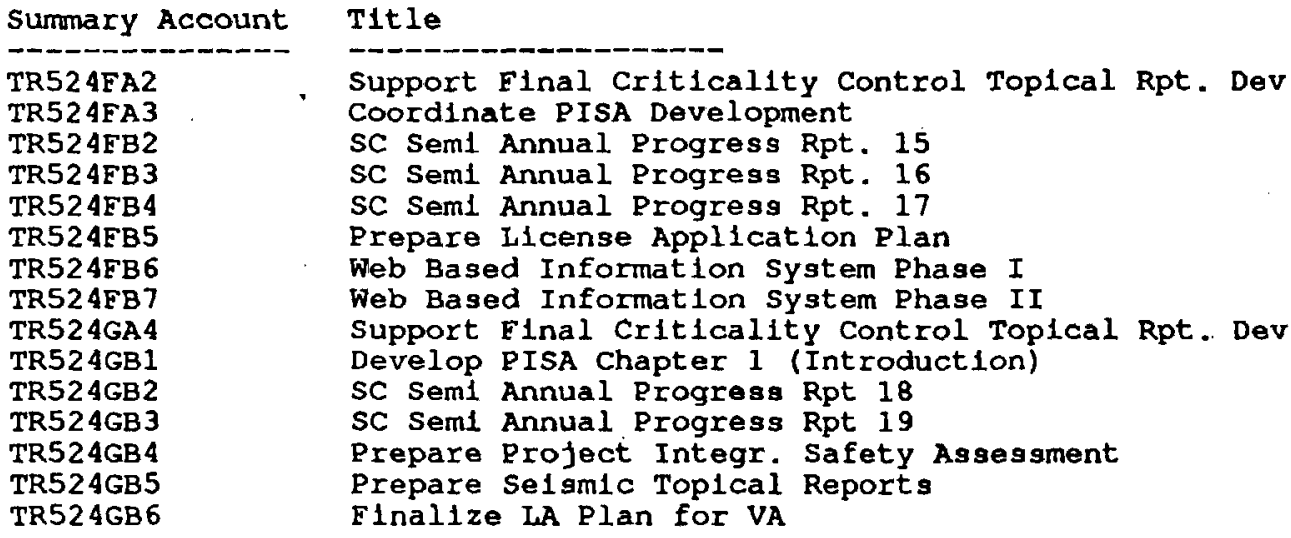

DELIVERABLES

\begin{tabular}{|c|c|}
\hline Deliv ID & Description/Completion Criteria \\
\hline PRI 5M3 & 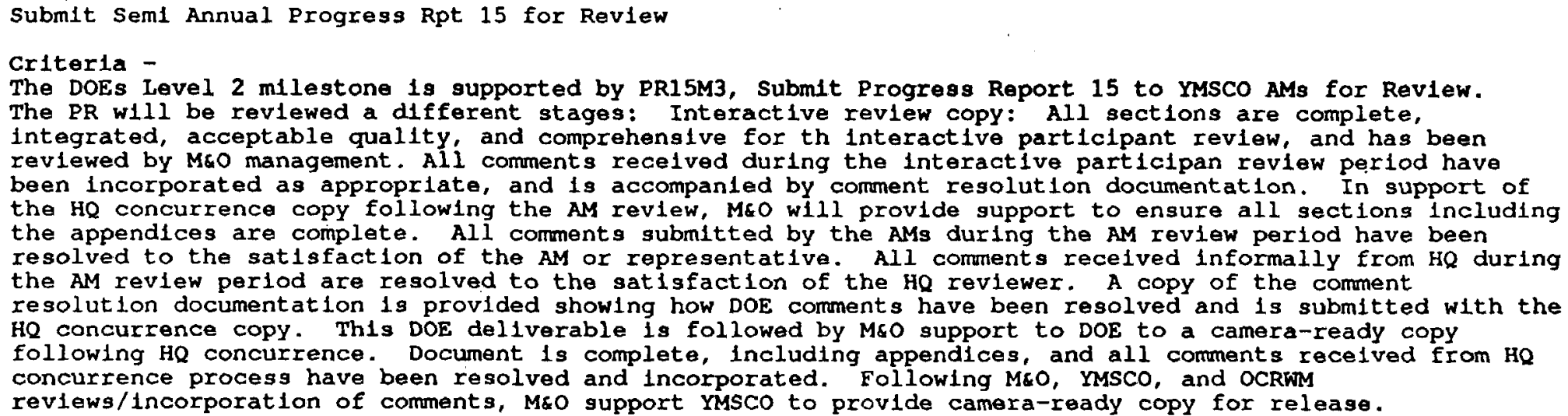 \\
\hline
\end{tabular}

Criterla -

The DOEs Level 2 milestone $1 \mathrm{~s}$ supported by PR16M3, Submit Progress Report 16 to YMSCO AMs for Review. The PR will be reviewed a different stages: Interactive review copy: All sectlons are complete, integrated, acceptable quality, and comprehensive for th interactive participant review, and has been reviewed by M\&O management. All comments recelved during the interactive participan review period have been 1ncorporated as appropriate, and is accompanied by comment resolution documeptation. In support of the HQ concurrence copy following the AM review, M\&O will provide support to ensure all sections including the appendices are complete. All comments submitted by the AMs during the AM revlew period have been resolved to the satisfaction of the AM or representative. All comments recelved informally from HQ during the AM review period are resolved to the sat lsfaction of the HQ reviewer. A copy of the comment resolution documentation $1 \mathrm{~s}$ provided showing how DOE comments have been resolved and $1 \mathrm{~s}$ submitted with the HQ concurrence copy. Th1s DOE deliverable is followed by MEO gupport to DOE to a camera-ready copy following $\mathrm{HQ}$ concurrence. Document is complete, including appendices, and all comments recelved from HQ 


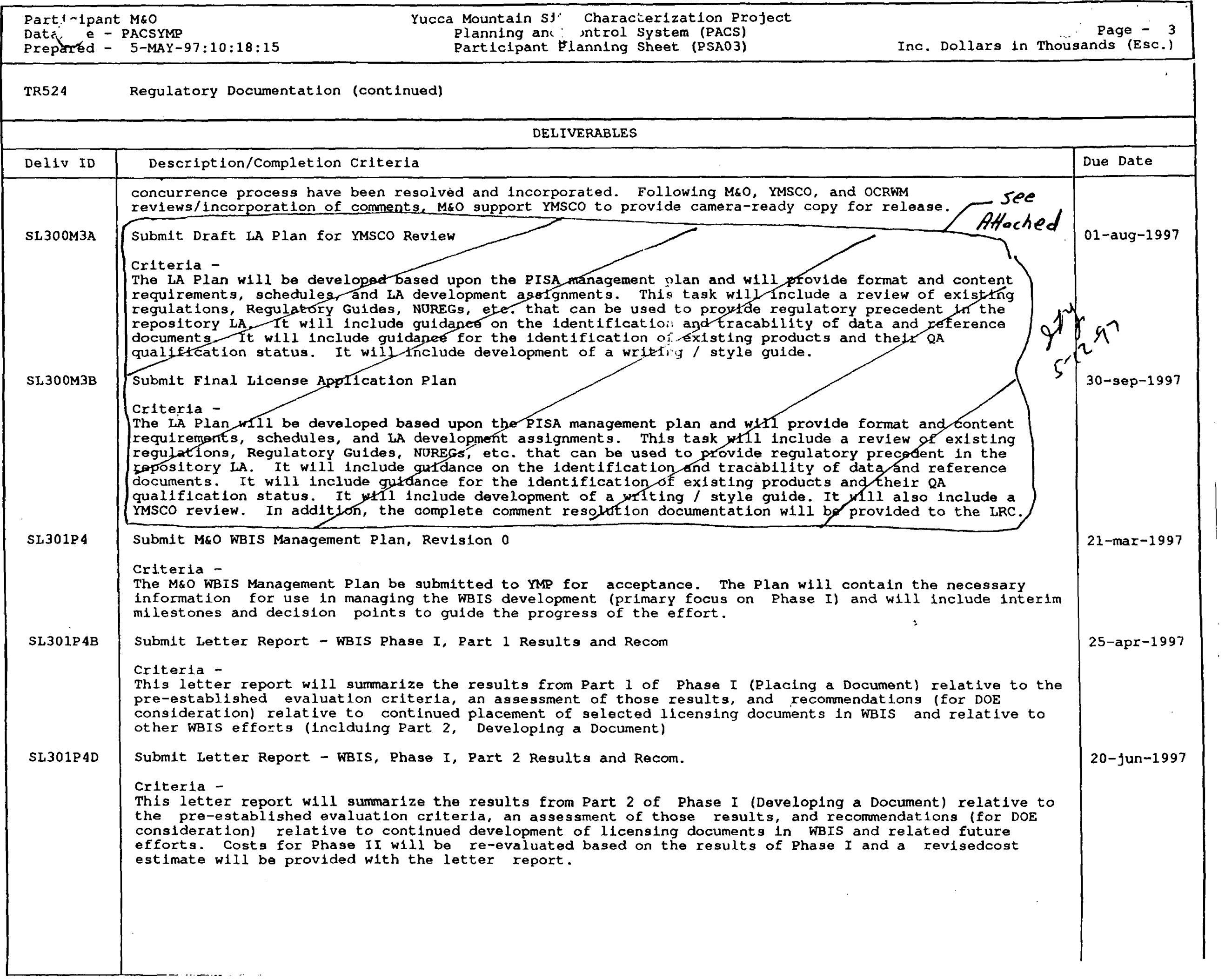




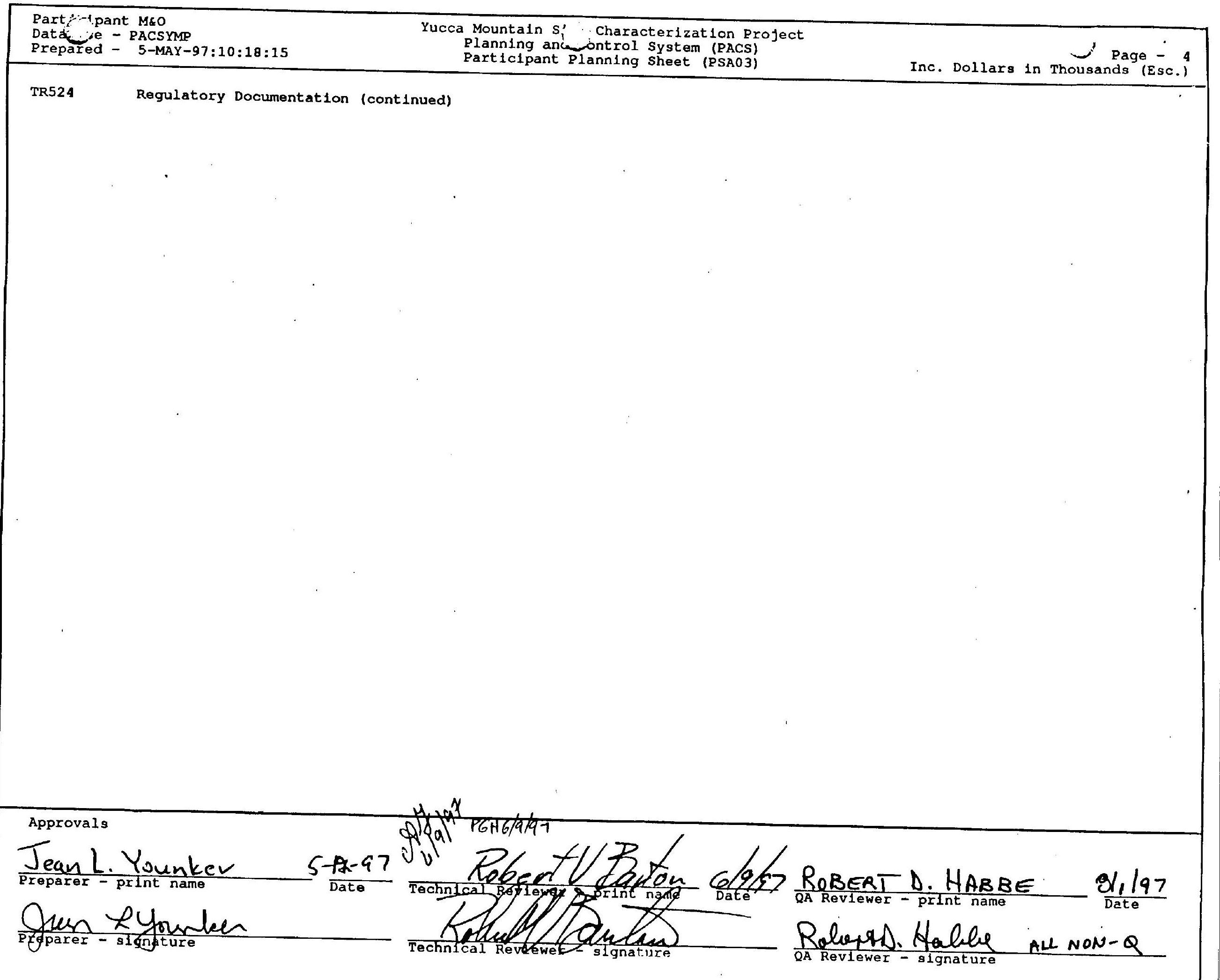

